\title{
Northeast Asian Regional Integration: Theoretical Perspectives, Current Realities, and Future Prospects*
}

\author{
Choi, Young Jong
}

(C atholic University of Korea)

$\langle$ CONTENTS $\rangle$

I . Introduction

II. Regional Integration Theories and Current State of Regional Integration in Northeast Asia

1. Theoretical Overview

2. Current State of Regional Integration in Northeast Asia
III. Key Issues in Northeast Asia Regionalism

1. Functional Needs or Political Will?

2. Disparities in the Level of Development

3. The Leadership Problem

4. Common Identity

IV. Future Prospect

- Keyword: regionalism, regional integration in Northeast Asia, Functionalism, political will, leadership problem, common identity, level of development

\section{【ABSTRACT】}

This paper analyzes the current state and the future prospect of Northeast Asian regionalism from the perspectives of various theories of regional integration. This paper identifies four key conditions for the success of regional integration: functional demands, leadership, common exigencies or sharing of strategic interests, and common identity. This study shows that Northeast Asia fails to meet these conditions at present, and the situation is likely to continue for quite a while. The most serious obstacle will continue to be the strategic rivalry between Japan and China. Another challenge to overcome is Japan's reluctance to integrate with less developed neighbors.

A plausible option for the successful integration in Northeast Asia is to take a gradual approach that will start from a Japan-South Korea FTA. This would bring

\footnotetext{
*This study is supported by the Research Fund 2007 of the Catholic University of Korea.
} 
together the two biggest democratic, capitalist economies in East Asia. Once established, it could be expanded into a trilateral FTA including China. However, this option cannot proceed if China is opposed. Then, Northeast Asia may have to continue boring functional cooperation.

\section{Introduction}

The global wave of regionalism has finally reached Northeast Asian, a hotspot of unprecedented economic dynamism and anachronistic nuclear threats. ${ }^{1)}$ The visualization of a FTA linking South Korea, China, and Japan has been undergoing a reality test ever since then Chinese Premier Zhu Rongji proposed it in November 2002 on the basis of a joint research project carried out by para-governmental research institutions in the respective countries. ${ }^{2)}$ Along with such a proposal, a bilateral FTA between South Korea and Japan has been in negotiation and may be around the corner, although the final stage of official negotiation has become stalled. Both the South Korean and Chinese governments are also showing keen interest in establishing their own bilateral FTA.

The leaders of South Korea, China, and Japan have regular trilateral meetings, and the three countries have also developed regular ministerial meetings on trade, finance, communication, and the environment. At the ASEAN+3 meeting in October 2003 in Bali, the "Plus Three" countries issued a Joint Declaration aimed at Promoting Trilateral Cooperation. The Declaration pledges further cooperation and dialogue on economic, cultural, educational, environmental, political-military, and security issues, and the leaders also agreed to set up a trilateral committee to promote and implement the cooperative agreements. This institutional arrangement, along with the rapid expansion of economic exchanges, has laid a strong foundation for trilateral cooperation.

1) Regionalism is a political ideology that places high value on the interests of a region. Regionalism usually centers on enhancing region's power and prestige. Regional interests can be promoted through political and economic cooperation, which are commonly referred to as "political regionalism" and "economic regionalism" respectively. Regionalism can be contrasted with nationalism and globalism. Meanwhile, regional integration is a process in which states enter into regional institutions in order to increase regional cooperation and diffuse regional tensions. In this sense, regionalism can proceed without regional institutionalization. See Norman D. Palmer, The New Regionalism in Asia and the Pacific (Lexington Books, 1991), pp.1-15.

2) Naoko Munakata, Transforming East Asia: The Evolution of Regional Economic Integration (Washington DC: Brookings Institution Press, 2006), pp.128-9. 
At the Seventh Trilateral Leaders' Meeting of South Korea, China and Japan held in Cebu in January 2007, the three leaders agreed to expand trilateral cooperation into the political and security realms by setting up a trilateral mechanism involving regular consultations among senior foreign affairs officials. They also expressed a shared desire to promote cooperation on trade, investment and energy, and they agreed to initiate trilateral investment negotiations as well. A number of new priorities were jointly named for trilateral cooperation, including finance, science and technology, public health, tourism, logistics and distribution, youth and teenager communications. The leaders agreed to promote cultural exchanges in a bid to enhance understanding and friendship among the people of the three countries. The three countries will jointly hold the "Year of Cultural Exchanges among China, Japan and Republic of Korea” in 2007."

However, rhetoric rarely guarantees action. While Northeast Asian regionalism has become a hot issue, nationalism continues to take precedence in regional politics. Chinese nationalism has clashed with Japanese and South Korean versions of nationalism. Japanese nationalism strains its neighboring countries. South Korean nationalism toward Japan has flared up quite often in recent years. The lack of trust among the three countries continues to pose formidable barriers that prevent them from forming a meaningful economic grouping.

In this sense, the current state of regionalism in Northeast Asia justifies neither pessimism nor optimism. As Rozman argues, economic liberals have been far too optimistic in stressing the primacy of economic factors in promoting regional integration in Northeast Asia, while realists have been far too pessimistic in stressing how security fears drive countries apart." Liberal political economists have paid little attention to the significant barriers to regionalism in Northeast Asia by assuming that economic interdependence will erode security fears. Realist predictions of conflict over disputed territories and counterbalancing China's rising power have failed to materialize.

This paper will analyze the current state and the future prospect of Northeast Asian regionalism from the perspectives of various theories of regional integration. This approach can be justified since most of the researches conducted by regional scholars on Northeast Asian regionalism in recent years are either policy-oriented or at the brainstorming stage. ${ }^{5)}$ Northeast Asia raises interesting theoretical questions concerning the

3) Kyodo News International, Jan. 14, 2007.

4) Gilbert Rozman, Northeast Asia's Stunted Regionalism (Cambridge University Press, 2004), pp.6-17.

5) Refer to papers presented at the annual conferences organized by Northeast Asia Intellectuals' 
slowness of regional integration when the countries were in the middle of rapid growth yet the sudden surge of regionalist interests (or regionalism) in recent years. If regional integration demands, as conventional theories suggest, a certain convergence of values, interests, and ideas, it will be useful for us to seriously evaluate the degree to which such a convergence exists among South Korea, Japan, and China. This endeavor leads us to examine the theories of regional integration in light of the current state of Northeast Asian regionalism. On the basis of this examination, it may be possible to give an assessment of the future prospects of regional integration in Northeast Asia.

\section{Regional Integration Theories and Current State of Regional Integration in Northeast Asia}

\section{Theoretical Overview}

Regional integration has both demand and supply sides. Functionalist approaches represent sophisticated theorizing about the demand side. They start from groups and individuals who are involved in trans-national economic exchanges and therefore have intense interests in breaking down barriers to economic exchange. Reduction of transaction costs, elimination of red tape, and removal of tariff and non-tariff barriers will increase the geographic scope of production and exchanges and enhance overall economic efficiency. The process of economic integration, however, involves not just economic exchanges but also rules and institutions. Even the simplest economic exchanges require regulations and standard setting as well as specification of property rights. Separate national legal regimes constitute the crucial source of transaction costs for those wishing to engage in exchanges across borders. ${ }^{6)}$

Although a well-developed demand side is necessary for regional integration, it is not sufficient. Without political mechanisms to provide leadership, aggregate interests, and

Solidarity Korea (NAIS Korea), which has been the most active as well as productive promoter of a Northeast Asian community. For a brief summary of the researches by NAIS Korea, see Jehoon Park, "Toward the Northeast Asian Community: Searching for a Model of Regional Integration in Northeast Asia," Paper Presented for the $5^{\text {th }}$ International Seminar Organized by NAIS Korea, Seoul, Korea, Feb. 20 2007.

6) Alec Sweet Stone and Wayne Sandholtz, "Integration, Supranational Governance, and the Institutionalization of the European Polity', in Wayne Sandholtz and Alec Stone Sweet, eds., European Integration and Supranational Governance (Oxford: Oxford University Press, 1998), p.11. 
convert them into policy, even the most intense interests may not achieve desired policy consequences. In this sense, regionalism has a supply side. Institutional arrangements, however, do not automatically come into being just because they are efficient. There are many potential regional arrangements that would be beneficial but have not come into effect. Efficiency at the regional level may be sidestepped by national or sub-national actors benefiting from the status quo.

Specifying the supply-side conditions of regional integration has been one of the major subjects of international relations theories and regional integration theories. One plausible answer coming out of this theoretical journey is the important role that could be played by a core area or a small group of committed members among the potential integrating countries. Successful regional arrangements have a hegemonic core, e.g., Germany or Germany-France in the case of the EU and the United States in the case of North America. Hegemonic stability theory argues that the presence of a hegemonic power increases the prospects for cooperation of all kinds. The ensuing theoretical development shows that, short of a single large power whose interests lie in integration, a small number of committed countries favorable to integration can help. Since regional integration contains aspects of public goods, the presence of a committed core of countries(the so-called privileged $\mathrm{k}$ ) that benefit from integration even in the face of free riding will facilitate integration.

In recent years, researchers have been paying increased attention to domestic politics, which is at the center of liberalism as well as liberal intergovernmentalism that emphasizes also the role of inter-governmental negotiations along with domestic politics. Their basic idea is that economic and social interests provide only the raw material of politics, but such interests have to be recognized and mobilized before they become active in politics. Therefore, liberal theorists focus their efforts on explaining the formation of groups pursuing their respective interests and the political process through which interests are converted into actual policies. Pluralist interest group theory, the logic of collective action, and institutionalist theory are instrumental in understanding how economic demands are translated into political results. Liberalism and liberal intergovernmentalism provide a sophisticated theory of preference formation regarding regional integration. ${ }^{7}$

Strategic concerns(e.g., concerns for relative power and opportunistic behavior) are at the center of realism and commonly are mobilized to show the difficulties of regional integration among sovereign states. The agenda of realist research has, however,

7) Andrew Moravcsik, The Choice for Europe (Ithaca: Cornell University Press, 1998). 
gradually shifted to explaining regional integration as an indisputable political reality. For example, Joanne Gowa ascribes the success of European integration to the stability of the bipolar system during the Cold War period. ${ }^{8)}$ Joseph Grieco explains the acceleration of European integration after the end of the Cold War as the result of the incentives held by secondary states in binding the powerful countries. ${ }^{9}$ According to realist logic, the existence of a security community will help bring about regional integration. History shows, however, not just that regional integration can proceed without a security community but also that many regional integration initiatives are driven by the incentive to counter integration in other regions or to increase collective strengths against external powers. Therefore, we may safely assume that sharing strategic interests (e.g., facing common threats or crises) will make it easier for a group of geographically contiguous countries to form a regional entity.

Finally, ideational factors like mutual trust or common identity deserve attention as facilitators of region integration. Mutual trust among member countries provides an important aspect of social capital to economic and political actors, and therefore many potential economic exchanges will not take place without it. Common identity will also facilitate integration, particularly the deepening of already existing regional entities. This concern belongs to early functionalists like Deutsch who focused on community and the development of "we-feelings." Constructivism is particularly strong in explaining the acceleration of European integration in recent years with the formation of a more cohesive European identity. ${ }^{10)}$ It is also not unusual for a group of countries that experience common threats or crises to develop a strong sense of community or common identity.

\section{Current State of Regional Integration in Northeast Asia}

In view of these underlying forces toward regional integration, the long stagnation of regional integration in Northeast Asia can be attributed to the deficiency of both the demand and supply of regional integration. For instance, according to neofunctionalism, integration is most likely to emerge among countries with a certain type of domestic environment, i.e., liberal democratic countries with advanced capitalist economies,

8) Joanne Gowa, "Bipolarity, Multipolarity and Free Trade," American Political Science Review, 83-4 (1989).

9) Joseph M. Grieco, "The Maastricht Treaty, Economic and Monetary Union, and the Neorealist Research Programme," Review of International Studies, 21-1(1995), pp.21-40.

10) Finn Laursen, "Theoretical Perspectives on Comparative Regional Integration," in Finn Laursen, ed., Comparative Regional Integration: Theoretical Perspectives(Ashgate, 2003), pp.18-20. 
differentiated social structures, and highly pluralistic interest group structures. ${ }^{11)}$ A transnational society has a better chance to emerge among such countries. Northeast Asia, however, does not meet these basic conditions. Societies there are still far from pluralistic in the Western sense and moreover they are separated by various border barriers and self-centered nationalisms. ${ }^{12)}$ Besides, formal regional institutions are underdeveloped. In short, both transnational societies and transnational institutions, the prime movers of regional integration in neofunctionalism, are weak in Northeast Asia.

Realists may point to the continuation of the cold war, an unstable power distribution, the absence of a security community, and the deficiency of a working regional leadership as important factors that have prevented integration in Northeast Asia. Intergovernmentalists would also take note of the divergence of national preferences concerning regional integration, particularly between Japan and China. ${ }^{13)}$ If we follow the logic of constructivism, Northeast Asia lacks coherence as a geopolitical entity, let alone any communal consciousness or common identity.

Until the financial crisis in 1997, Northeast Asian countries, with their impressive economic track records, had not experienced common exigencies that might justify joint actions. They have been impressive domestic adjusters and therefore slower than the United States and European states in recognizing the possible benefits of external adjustment via collective regional action. Northeast Asian states maintained a high degree of domestic economic control, and therefore domestic adjustments were both available and feasible. The nationalistic nature of their economic policies was reinforced by close government-business ties. ${ }^{14)}$ All these factors had long deterred any serious debate about regional integration that might have gone beyond intergovernmental cooperation.

The seed of Northeast Asian regionalism was laid in 1993 and 1994, prior to the economic crisis in 1997, when the ASEAN countries(at that time only six) invited South Korea, Japan, and China to join them in broader discussions. Since then, the APT ("ASEAN plus three") forum has become the foundation for the current discussions on

11) Haas Ernst B. and Philippe C. Schmitter, "Economics and Differntial Patterns of Political Integration: Projections about Unity in Latin America," International Organization, 18-3 (1964), pp.705-37.

12) Rozman(2004), pp.18-9.

13) Young Jong Choi, "China-Japan Relations and the East Asian Regionalism," in Chul Koo Woo and Jinwoo Choi, eds., Korea and China in the New Global System(Seoul: Korean Association of International Studies, 2002), pp.219-34.

14) Peter J. Katzenstein and Takashi Shiraishi, eds., Network Power: Japan and Asia(Ithaca: Cornell University Press, 1997), p.3. 
Northeast Asian regionalism. There is no denying that a degree of convergence of national interests among South Korea, Japan and China contributed to the launching of a drive for regional cooperation in Northeast Asia.

However, Japan and China have been widely apart in their national preferences toward specific details about economic integration in Northeast Asia as well as in East Asia as a whole. ${ }^{15)}$ At present, both countries are competing intensely to pull the ASEAN into their respective spheres of influence by offering attractive FTAs deals with ASEAN countries. ${ }^{16)}$ Although Japan and China are reluctant to take the leadership role necessary for the provision of various public goods for regional cooperation, they have struggled to prevent the other from gaining a dominant position in the region. ${ }^{17)}$ Meanwhile, South Korea, a secondary power in the region, has been the country that has taken the initiative for regional cooperation.

If identity determines the boundaries of a region, as constructivists argue, Northeast Asia has a stronger common identity now than a decade ago when the Northeast Asian three started gathering as a part of the ASEAN+3 meeting. It is, however, still unclear what constitutes the Northeast Asian-ness or Northeast Asian identity. Questions also remain regarding the extent of the effects this fledgling collective identity may have on individual countries' policies and ultimately on regional cooperation. The divergence of historical experiences, socio-economic diversities, and conflicting political ideologies still pose formidable barriers against forging a common identity in Northeast Asia. Worse still, neoliberal consensus, which has propelled integration in other regions, is weak in Northeast Asia. Another burden that the constructive argument must deal with is refuting the powerful claim that ideas are only tenuously linked as an independent variable to regional integration. ${ }^{18)}$ The surge of interests in functional arrangements like bilateral FTAs indicates that it is rational calculation of national interests, rather than common identity, which drives Northeast Asian regionalism today.

Domestic politics does not offer a fertile ground for regional cooperation in Northeast Asia. According to functionalist approaches, the pressure for regional integration becomes stronger along with democratization and economic liberalization. Even in the

15) Munakata(2006), pp.134-67.

16) Munakata(2006), pp.121-3.

17) Stuart Harris and Greg Austin, "Japan, China and Regional Order," in Peter Drysdale and Dong Dong Zhang, eds., Japan and China: Rivalry or Cooperation in East Asia(Canberra, Australia: Asia Pacific Press, 2000), pp.143-4.

18) Young Jong Choi and James A. Caporaso, "Comparative Regional Integration," in Walter Carlsnaes, Thomas Risse, and Beth Simmons, eds., Handbook of International Relations (California: Sage Publications, 2002), p.490. 
most liberal, democratic countries like Japan and South Korea, however, the state is still highly interventionist; protectionist forces are influential in making foreign economic policies; and mercantilist orientation guides their commercial and industrial policies.

\section{Key Issues in Northeast Asian Regionalism}

\section{Functional needs or political will?}

For every political adventure, be it a world revolution or a regional integration, there have been intense debates concerning whether objective conditions or human will matters more. In the case of regional integration, functionalist approaches, mainly based on the experience of Western Europe, emphasize objective conditions(the socalled degree of interdependence according to Haas and Schmitter) like the size of units, rate of transactions, pluralism, elite complementarity, etc. Political integration comes automatically as the degree of interdependence increases. At present, Northeast Asian economies are highly integrated, but such integration is currently limited to the economic realm. If economic interdependence begins to spill over into other areas, functionalist approaches would suggest that a deeper process including political integration will be launched. The best strategy for Northeast Asian countries to achieve regional integration, they would argue, would be to continue this rather boring functional cooperation.

Then, what is the place for the political will to integrate, particularly the will to overcome the insufficiency of objective conditions? It is possible that the logical arrow may move in the opposite direction from the functionalist argument. That is to say, regional integration may progress if a strong political will exists even without objective conditions prescribed by functionalists. That is why regionalism has become a global phenomenon beyond Europe and North America. However, many of the regional integration agreements among developing countries(namely South-South or S-S integration), motivated primarily by political goals like enhancing bargaining leverage against outsiders, have either collapsed or never taken off. ${ }^{19)}$ The poor record for politically-initiated regional integration schemes reiterates the importance of functional demands for integration. This fact cautions against overly hasty, politically motivated efforts at integration in Northeast Asia.

19) World Bank, Trade Blocs(New York: Oxford Press, 2000), p.25. 
This concern leads us to critically examine South Korea's effort to facilitate Northeast Asian integration. Northeast Asia has been at the center of President Roh's foreign policy. He invested a significant portion of his diplomatic assets in a Northeast Asian integration project while both China and Japan showed little interest. President Roh was mainly motivated by his political ambition to bring peace to the Korean peninsula. He saw no major breakthrough in the process and invited only worries and cynicism from the two neighbors. South Korea's political approach to regional integration(i.e., to place Northeast Asian integration high in foreign policy priorities) did not pay off, offering benefits in terms of peace and prosperity since its goal was overly ambitious, by treating a regional community as a panacea for all of its security and economic ills, and it was too hastily pursued without the consent of neighboring countries.

However, there is no logical imperative in regional integration theories that every regional integration attempt has to end up with political integration by climbing the ladder from FTA through customs union, common market, and economic union. Political union is an extreme form of regional integration, and regions of the world form various types of regional communities. Regional communities may vary in terms of the degree of institutionalization or, more specifically, the degree of the pooling of national sovereignty. Therefore, Northeast Asian regional integration can take a gradual, modest, and pragmatic form. As long as South Korea, Japan, and China share more or less a sense of common destiny, while showing a degree of willingness to sacrifice national interests for the good of regional interests, peace and prosperity may come to the region without formal institutional integration. What matters is the size of benefits, and it would depend on various factors like the degree of institutional integration.

\section{Disparities in the Level of Development}

History shows that the level of economic development has been a decisive factor to the success of economic integration. For example, most integration agreements involving high-income countries(namely North-North or N-N integration) have survived, successfully locking in their policies. The record among developing countries(namely South-South or S-S integration) is very poor. Northeast Asian integration would involve a case of North-South(N-S) integration, in which a huge income gap exists between Japan and China with Korea in the middle.

A typical North-South integration involves not only the fear of economic domination by the Northern members but also serious disturbances caused by relocation of industries on both sides. For example, labor-intensive production activities will move 
toward lower-wage Southern countries. Therefore, any serious N-S integration requires a greater loss of sovereignty and policy autonomy, greater political commitment, and more demanding domestic reforms than other types of integration. Difficult negotiations usually end up with the largest concessions being demanded of the Southern side. The recent increase in the number of $\mathrm{N}-\mathrm{S}$ integration has been led by several willing Southern countries like Chile, Mexico, and former Soviet bloc countries. In addition, the Northern developed countries should have a sufficient political leverage against the Southern countries in order to mitigate a race to the bottom in the social standards, exodus of labor-intensive industries, and grueling domestic restructuring of the Northern sides. ${ }^{20)}$

Will China(and to a degree South Korea) act like Chile or Mexico by accepting the tough domestic reforms necessary to appease Japan's concerns? Does Japan have enough leverage against China? If power can be measured, as Keohane and Nye argue, by the asymmetry in economic interdependence(namely differences in "sensitivity" and "vulnerability"), less dependent countries enjoy a point of leverage that can be applied to impose demands on more dependent states. ${ }^{21)}$ in this sense, China has "go it alone" power based on its huge domestic markets, in addition to which the Chinese government enjoys considerable leeway to use economic statecraft thanks to the relative weakness of domestic society and strong autonomy from domestic politics. Considering China's long ambition to place itself at the center of the world, it will be a daunting challenge to harness China's rising power in the interests of regional cooperation.

The fact that China, still a developing country, is a political giant defies the logic of typical N-S integration to the Northeast Asian case. A successful Northeast Asian integration requires a new model of $\mathrm{N}-\mathrm{S}$ integration, into which China's legitimate role has to be duly incorporated. In that case, Northeast Asia may have to settle with low quality FTAs exempting "sensitive products" and new trade issues like harmonization, service, and intellectual properties. ${ }^{22}$

However, China may contribute to Northeast Asian regional integration either by transforming itself into an advanced, democratic, capitalist country, or by alleviating security concerns arising from the rapid expansion of its power. While the former will take much time, the latter is likely to be a more plausible option. China is currently

20) Young Jong Choi, "East Asian Regionalism and South Korea's FTA Strategy," The Korean Journal of International Relations, 44-5(2004), pp.96-8.

21) Robert O. Keohane and Joseph Nye, Power and Interdependence(Harper Collins Publishers, 1989), pp.11-9.

22) Fred C. Bergsten, "China and Economic Integration in East Asia: Implications for the United States," Policy Brief 07-03(Peterson Institute for International Economics, March 2007), p.5. 
paying close attention to Northeast Asian security regionalism. China adopted a "new diplomacy" in the early 1990s on the basis of two principles: one is to engage itself actively in international affairs and the other is to maintain stable relationships with major powers. ${ }^{23)}$ This change has made security regionalism in Northeast Asia more feasible, which in turn is expected to facilitate economic and political integration in Northeast Asia in the long run.

\section{The Leadership Problem}

At present, China is not ready for further liberalization beyond the requirements imposed by the WTO. The ASEAN-China FTA is in a sense a token proposal driven by political motivations. ${ }^{24)}$ Closer cooperation with ASEAN can serve several political purposes for the Chinese government. That is to say, it may tame the fear of 'China threat' among East Asian countries, particularly ASEAN members; serve its foreign policy goal of 'anti-hegemonism' and undermine Japan's dominant position in Southeast Asia. From the perspective of China, the same logic can be applied to Northeast Asian integration.

Currently, Japan has neither a clear vision for an integrated Northeast Asia nor a capability or willingness to open up domestic markets to its neighbors. Japan is just a commercial giant without much military strength or soft power. Japan is disadvantaged, as compared with China, in approaching Northeast Asia since its options are tightly constrained by the need to maintain an amicable relationship with the United States. Historical animosity also runs deep with China and South Korea.

Under the circumstances, hegemonic leadership cannot be expected in Northeast Asia. ${ }^{25)}$ Joint leadership by Japan and China may be an alternative. ${ }^{26)}$ However, the intense rivalry between the two makes this an unlikely option at this point. Another possibility is to make Northeast Asia a region without a leader. Region points out that a leadership role for any state will reinforce the historical suspicions of neighboring states, limiting the prospects for forming a regional identity. ${ }^{27)}$ In this case, South Korea

23) Yongtao Liu, "Northeast Asian Security Regionalism: A Chinese Perspective," Paper Presented for the $5^{\text {th }}$ International Seminar Organized by NAIS Korea, Seoul, Korea, Feb. $20^{\text {th }}, 2007$.

24) Bergsten(2007), p.4.

25) Edward J. Lincoln, East Asian Economic Regionalism(The Brookings Institution, 2004), pp. 231-49.

26) Rozman(2004), pp.319-28.

27) Rozman(2004), pp.369-70. 
can play the leadership role as a political entrepreneur.

\section{Common Identity}

The importance of ideas or shared identities cannot be easily discounted. The federalist idea was behind the early development of European integration. Early functionalists like Karl Deutsch identified the formation of common identity as the driving force of regional institutional integration. Since then, ideas, along with power and interests, have drawn scholarly interest in the study of regional integration. Transnationalism, which is different from intergovernmentalism, presupposes that beyond shared interests there should be a degree of common identity pushing further institutional integration.

However, questions remain concerning the role of identity. Whether and how much does identity matter as an independent variable to regional integration? Can a regional identity be forged without sharing solid common interests? What constitutes Northeast Asian identity? Does it necessarily differ from Western values, cultures and identities? At present, any regional identity is at best vague in Northeast Asia, and common interests are not strong enough to further regional integration initiatives. Nationalism and national economic interests loom larger than regionalism and regional economic interests. In order to break the impasse surrounding regional integration, however, Northeast Asia may take the detour of changing its collective identity first so as to expand the overlap among the national interests of its members.

At present, Northeast Asia faces the dual challenges of identifying a common identity or common culture while at the same time coming up with an appropriate strategy by which to foster them. The region can halve the burden by simply accepting that Northeast Asia does not have to be unique or different from the West in terms of culture. Although the governments of South Korea, Japan, and China agreed to celebrate 2007 as the "Year of Cultural Exchanges," in fact many proposed cultural exchanges(e.g., music, cartoon, movies, TV drama) are already expanding quite rapidly with the result that their popular cultures are not much different, either from one another or from Western culture. ${ }^{28)}$ Continued economic prosperity and, possibly, further democratization in China will accelerate the formation of a Northeast Asian culture or identity in line with individualism, consumerism, and other universal values like human

28) T.J. Pempel, "Conclusion: Tentativeness and Tensions in the Construction of an Asian Region,” in T.J. Pempel, ed., Remapping East Asia: the Construction of a Region(Ithaca and London: Cornell University Press, 2005), pp.260-4. 
rights, democracy, and market economy. Since common culture or common identity is susceptible to domestic political whims if it is found only at the elite level, there is greater strength when values are shared by average people throughout the region. Only then can regional integration be locked in. In this sense, democratization and liberalization in Northeast Asia are crucial to the formation of a common regional identity.

\section{Future prospects}

Conventional theoretical approaches predict that regional integration in Northeast Asia is but a distant possibility. This paper identifies four key conditions for the success of regional integration: functional demands, leadership, common exigencies or sharing of strategic interests, and common identity. Northeast Asia fails to meet these conditions at present, and the situation is likely to continue for quite a while. The most serious obstacle will continue to be the strategic rivalry between Japan and China. Many approaches, particularly those belong to liberal/functionalist traditions, predict that democratization and further liberalization in China will dramatically increase the chance of successful integration among the three major economies in Northeast Asia.

Another challenge to overcome is Japan's reluctance to integrate with less developed neighbors. Particularly, Japan's fear of a powerful, increasingly unruly China can be justified from the recent increase in both the number and intensity of bilateral trade disputes. Japan is troubled most by China's absence of a predictable legal system, the primitive physical infrastructure in many of China's regions, and recently by the blatant use of economic sanctions. For example, Japan imposed in 2001 temporary tariffs on leeks, shiitake mushrooms and tatami straw from China, which was inundating the Japanese markets. The tariffs were, however, removed because of China's retaliatory action against Japanese vehicles, mobile phones, and air conditioners. South Korea had a similar experience of an unruly China in a series of bilateral trade conflicts, most blatantly during the "garlic war" of 2000. In this sense, South Korea and Japan share common interests in going trilateral. Not only will this maximize the benefits of free trade but it could also serve to transform China into a more reliable and respectable trade partner.

One plausible option for the successful integration in Northeast Asia is to take a gradual approach that will start from a Japan-South Korea FTA. This would bring together the two biggest democratic, capitalist economies in East Asia. Once 
established, it could be expanded into a trilateral FTA including China. This may gradually expand to cover the whole region similar to the widening of EU to other parts of Europe. However, this option cannot proceed if China is opposed. China has already become a key regional player with its huge domestic markets, strong growth potential, and fast-growing political weight. Under this circumstance, Northeast Asia may have to continue pursuing boring functional cooperation at all levels, e.g., political, social, cultural, legal, economic, etc. However, the current interest in Northeast Asian regionalism has the potential to bring regional countries closer into a form of regional community, although different from EU. With burgeoning regionalism at hand, Northeast now is much more secure and prosperous than a decade ago. 


\section{REFERENCES}

Bergsten, Fred C. "China and Economic Integration in East Asia: Implications for the United States.” Policy Brief 07-03. Peterson Institute for International Economics (March 2007).

Choi, Young Jong. "China-Japan Relations and the East Asian Regionalism." In Chul Koo Woo and Jinwoo Choi (eds), Korea and China in the New Global System. Seoul: Korean Association of International Studies, 2002.

Choi, Young Jong. "East Asian Regionalism and South Korea's FTA Strategy." The Korean Journal of International Relations, 44-5 (2004).

Choi, Young Jong and James A. Caporaso. “Comparative Regional Integration." In Walter Carlsnaes, Thomas Risse, and Beth Simmons (eds), Handbook of International Relations. California: Sage Publications, 2002.

Choi, Young Jong and Nae Young Lee. "A Comparative Study of Regionalism in East Asia and the Americas." Asian Perspective, 26-3 (2002).

Drysdale, Peter and Dong Dong Zhang, eds. Japan and China: Rivalry or Cooperation in East Asia. Canberra, Australia: Asia Pacific Press, 2000.

Gowa, Joanne. "Bipolarity, Multipolarity and Free Trade." American Political Science Review, 83-4 (1989).

Grieco, Joseph M. "The Maastricht Treaty, Economic and Monetary Union, and the Neo-realist Research Program.” Review of International Studies, 21-1 (1995).

Haas, Ernst B. and Philippe C. Schmitter. "Economics and Differential Patterns of Political Integration: Projections about Unity in Latin America.” International Organization, 18-3 (1964).

Katzenstein, Peter J. and Takashi Shiraishi, (eds). Network Power: Japan and Asia. Ithaca: Cornell University Press, 1997.

Keohane, Robert O. and Joseph Nye. Power and Interdependence. Harper Collins Publishers, 1989.

Laursen, Finn. "Theoretical Perspectives on Comparative Regional Integration." In Finn Laursen (ed). Comparative Regional Integration: Theoretical Perspectives. Aldershot, UK and Burlington, US: Ashgate, 2003.

Lincoln, Edward J. East Asian Economic Regionalism. The Brookings Institution, 2004. 
Mattli, Walter. The Logic of Regional Integration: Europe and Beyond. Cambridge: Cambridge University Press, 1999.

Munakata, Naoko. Transforming East Asia: The Evolution of Regional Economic Integration. Washington, DC: Brookings Institution Press, 2006.

Moravcsik, Andrew. The Choice for Europe. Ithaca: Cornell University Press, 1998.

Palmer, Norman D. The New Regionalism in Asia and the Pacific. Lexington Books, 1991.

Park, Jehoon. "Toward the Northeast Asian Community: Searching for a Model of Regional Integration in Northeast Asia." Paper Presented for the $5^{\text {th }}$ International Seminar Organized by NAIS Korea, Seoul, Korea, Feb. 20 2007.

Pempel, T. J., ed. Remapping East Asia: the Construction of a Region. Ithaca and London: Cornell University Press, 2005.

Rozman, Gilbert. Northeast Asia's Stunted Regionalism: Bilateral Distrust in the Shadow of Globalization. Cambridge: Cambridge University Press, 2004.

Stone Sweet, Alec and Sandholtz, Wayne. "Integration, Supranational Governance, and the Institutionalization of the European Polity." In Wayne Sandholtz and Alec Stone Sweet (eds), European Integration and Supranational Governance. Oxford: Oxford University Press, 1998.

World Bank. Trade Blocs. New York: Oxford Press, 2000. 